\title{
Effects of Kagan Structure Instruction on College of Education Students' Performance in Basic Science in Ekiti State, Nigeria
}

\author{
Olatunbosun, Segun Mobolaji (Ph.D) ${ }^{1} \quad$ Adeyeye, Adekemi Sarah ${ }^{1} \quad$ Ogunyebi, Tunji Henry $^{2}$ \\ 1.Department of Science Education, Ekiti State University, Ado-Ekiti, Nigeria \\ 2.Department of Integrated Science, College of Education, Ikere, Ekiti State, Nigeria
}

\begin{abstract}
This paper examined the effects of Kagan structures and classroom teaching on college of Education students' performance in Basic science in Ekiti State. The study adopted a quasi-experimental pre-test, post-test, control group design. Four null hypotheses were generated and tested at 0.05 level of significance. The sample consisted of 80 Basic Science students selected from part two 2017/18 academic session through simple random sampling technique. The instrument that was used for the study was Basic Science Achievement Test (BSAT). It is a selfdesigned instrument that consisted of information on bio-data of the respondents and 40 multiple-choice items. The data were analyzed using inferential statistics of t-test. The study found that there was a significant difference between the posttest means scores of students exposed to Kagan instruction and conventional strategies. It was also revealed in the study that there was no significant difference between the posttest means scores of male and female students exposed to Kagan instruction and conventional strategies. Based on these findings, it was recommended among other things that the college management should organize a seminar among the lecturers of the institution on the effective use of Kagan instruction strategies in their various classes to enhance performance Keywords: Kagan structures, Instruction, Performance, Basic Science, College of Education students

DOI: $10.7176 / \mathrm{JEP} / 11-3-08$
\end{abstract}

Publication date: January $31^{\text {st }} 2020$

\section{Introduction}

The Technological development of a developing country like Nigeria largely depends on the effective teaching and learning of science subjects. Consequently, Nigeria's educational policies and programs are being directed toward the sciences and Basic Science being the core and foundation of science, which is the pivot on which other Science subjects revolve.

Emmanuel (2009) asserted that no other subject forms a strong binding force among the various branches of science as Basic Science; and without it knowledge of science often remains superficial. The importance of Basic Science cannot be over emphasized. It is the base of all sciences and environment professions. Some authorities have described it as "Queen of the Sciences" while to others is a tool with which all scientific and social analyses are carried out. Basics Science is so important that all students must learn and pass it at the Junior Secondary examination level before they can advance to higher Senior Secondary Education. Thus, performance in Senior school Science is a function of performance in Basic Science in Junior Secondary Examination Various studies have been carried out on the factors that affect students' academic performance in schools, colleges and universities. Some of the factors identified and reported to have affected the academic performance of students in these different settings are: students effort, previous or prior educational performance, self-motivation, number of hours of study per day, admission points, different entry qualification among others (Farooq, Chaudry, Shafq\&Berhanu, 2011; Ali., 2013).

In the past, a student's success was based on the amount of information are could memorize, however in today's information age, conceptional knowledge is more important. (Huitt, 2007). For our entire lives, we interact with others within our surroundings in order to acquire knowledge (Lerner and Cierro, 2004). Lerner and Cierro (2004) suggested that the ability to talk, think and to gain both self-confidence and self-control is acquired through this interaction. These daily interactions and contacts with others around us can also be used to teach children simple skill needed to cooperate with others (Lerners and Cierro, 2004). The content that is taught, depends on the method of classroom structure selected by the teacher (Cole, 2008). It is therefore more pertinent that we should continue to seek methods and variables which would improve students' mastery of the subject and consider some strategies especially those that have to do with peer learning. Among these is Kagan structure learning approach that helps students work in groups and learn. Kagan operates within the parameter of cooperative learning in which students need to work together to succeed in a task. Kagan (2013) posited that kagan cooperative learning structures are instructional strategies that are content-free. They facilitate teaching and learning any content. They are used over and over with different content to create fresh activities. They are carefully designed sequence of steps that organize the interaction of students with each other the academic content and the instructor. According to Wiklpedia, peer instructional strategies as epitomized by Kagan instructions involve learners' engagement in a common task in which each individual depends on and is accountable to one another. The New South Whales Educational Standard Authority (NESA) opined that students work better in team to enhance their academic 
practice. Kagan instruction $(\mathrm{KI})$ is a student centered approach in which lectures are interspersed with short conceptual questions designed to challenge students to think about the material as it is being presented. Students assigned require reading assignments before coming to class to make up for lost lecture time. The Kagan instruction method was generally defined as a method in which peer help each other one-to-one, learning from each other, sharing their success for a common purpose (Graybeal \& Stodolsky, 1985). In order to excute Kagan Cooperative Learning, Davidson (1994) and Kagan (2011) were of the opinion that it is necessary for teachers to learn structures and incorporate them into their lessons. What consist of Kagan structures are interaction sequences that implement four basic principles symbolized as PIES (Positive, Interdependence, Individual, Accountability, Equal Participation and Simultaneous Interaction). These four principles are to be applied in teaching the students.

Kagan structures learning strategy if well implemented could be gender, friendly like other co-operative learning strategies. In a study conducted by Goodings and Merz (2011), they found that students' academic performance and attitude were enhanced irrespective of gender differences, after participating in a collaborative group lesson.

\section{Statement of the Problem}

The poor performance of some undergraduates in Nigeria has been widely reported. It is also observed that the performance of many students in higher institutions is not encouraging due to in appropriate instructional strategies which do not allow the students to be actively involved in the lectures (Ali, 2013). The students just listen to lecturers without concentration or distracted by some factors that may result in reduced assimilation and low achievement. These situations seem to have diverse effects on the effective teaching and learning of science. It is against these mentioned observations that this research was carried out to investigate the effects of Kagan instructional strategies on college of education students' performance in Basic Science in Ekiti state.

\section{Purpose of the Study}

The purpose of this study was to examine the effect of Kagan instruction on College of Education students' performance in Basic Science in Ekiti State. The study also intends to examine possible effect of gender on college students' performance in Basic Science. The outcome of this effort will be used to suggest steps that can enhance and improve Science performance.

\section{Research Hypotheses}

The following null hypotheses were generated and tested;

1. There is no significant difference between the pretest mean scores of subjects exposed to the Kagan instruction and conventional strategies.

2. There is no significant difference between the posttest mean scores of students of students exposed to Kagan instruction and conventional strategies.

3. There is no significant difference between the posttest mean scores of male students exposed to the kagan instruction and conventional strategies.

4. There is no significant difference between the posttest mean scores of female students exposed to the Kagan instruction and conventional strategies

\section{Research Design}

The study was a quasi-experimental pre-test, post-test, control group design. The pre-test was to establish the knowledge base line of the students that were used for the study while the post-test will measure the level of academic performance of the students after treatment. In this study, two already existing, or intact groups were used, one of them as the experimental group and one of them as the control group.

The design of the study is given as follows:

$\begin{array}{lllll}\text { Experimental Group }= & 0_{1} & \mathrm{X}_{1} & 0_{2} \\ \text { Control Group }= & 0_{3} & \mathrm{X}_{2} & 0_{4}\end{array}$

Where $0_{1}, 0_{3}$ represent pre-test, $X_{1}=$ Kagan instruction, $X_{2}=$ Conventional method. Also, $0_{2}, 0_{4}$ represent posttest.

\section{Population}

The population of the study consisted of all Basic Science Students in College of Education, Ikere Ekiti, who are in the second year of the study (N.C.E part 2) for 2017/18 academic session. They are made up of boys and girls from the department Science and Technology Education. The total number of part II students for the session is 95 , comprising 36 boys and 59 girls.

\section{Sample and Sampling Techniques}

The sample for this study consisted of 80 Basic Science students selected from part two (2017/18 academic session) 
through simple random sampling. Proportional random sampling was also used to select 35 boys and 45 girls to ensure gender equality.

\section{Research Instrument}

This instrument that was used for this study is Basic Science Achievement Test (BSAT). It is a self-designed instrument. Section A of the BSAT consisted of information on bio-data of the respondents while Section B consisted of 40 multiple-choice items that covers all the content of the chosen topics used as achievement test.

\section{RESULTS}

HO1: There is no significant difference between the pretest mean scores of students exposed to Kagan instruction and conventional strategies. In testing this hypothesis, the mean total score and standard error obtained from the pretest mean scores of students exposed to Kagan instructional and conventional strategies were subjected to t-test analysis at 0.05 level of significance.

Table 1: The t-test showing the pretest mean score of students exposed to Kagan instructional and conventional strategies.

\begin{tabular}{|l|l|l|l|l|l|l|l|}
\hline Group & N & Mean & SD & Df & t-cal & t-table & result \\
\hline Kagan Instruction & 40 & 27.33 & 10.40 & & & & \\
& & & & 78 & 4.39 & 1.96 & Significant at $<0.05$ \\
\hline Conventional method & 40 & 13.63 & 16.24 & & & & \\
\hline
\end{tabular}

Table 1 shows that the mean score of students exposed to kagan instruction is 27.33 with standard deviation of 10-40, while the mean score of students exposed to conventional method is 13.63 with standard deviation of 16.24. The $\mathrm{t}$-calculated is 4.39 while the $\mathrm{t}$-table is 1.96 . Thus the $\mathrm{t}$-calculated is grater than the $\mathrm{t}$-table value; therefore, the null hypothesis is rejected.

$\mathbf{H O}_{2}$ : There is no significant difference between the posttest mean scores of students exposed to kagan instructional and conventional strategies

In testing this hypothesis, the mean total score and standard errors obtained from the posttest mean scores of students exposed to kagan instructional and conventional strategies were subjected to t-test analysis at 0.05 of significance.

Table 2: the t-test showing the posttest mean score of student exposed to kagan instructional and conventional strategies.

\begin{tabular}{|l|l|l|l|l|l|l|l|}
\hline Group & N & Mean & SD & Df & t-cal & t-table & result \\
\hline Kagan Instruction & 40 & 11.46 & 3.71 & & & & \\
& & & & 78 & 14.21 & 1.96 & Significant at $<0.05$ \\
\hline Conventional method & 40 & 7.66 & 2.85 & & & & \\
\hline
\end{tabular}

Table 2 shows that the mean score of students exposed to kagan instructional strategies is 11.46 with standard deviation of 3.71, while the mean score of students exposed to conventional method is 7.66 with standard deviation of 2.85. The t-calculated is 14.21 while the table value is 1.96 . Thus, the t-calculated is greater than t-table value, and therefore, the null-hypothesis is rejected. This implies that there is significant difference between posttest mean scores of students exposed to kagan instructional and conventional strategies.

HO$_{3}$ : There is no significant difference between the posttest mean scores of male students exposed to Kagan instructional and conventional strategies.

In testing this hypothesis, the mean total score and standard error obtained from the posttest mean scores of male students exposed to Kagan instructional and conventional strategies were subjected to t-test analysis at 0.05 level of significance.

Table 3: The t-test showing the posttest mean scores of male students exposed to kagan instructional and conventional strategies.

\begin{tabular}{|l|l|l|l|l|l|l|l|}
\hline Group & N & Mean & SD & Df & t-cal & t-table & result \\
\hline $\begin{array}{l}\text { Kagan Instructional } \\
\text { strategy }\end{array}$ & 20 & 49.33 & 18.64 & 33 & 1.87 & 1.96 & Not Significant at $<0.05$ \\
\hline Conventional method & 15 & 46.21 & 18.31 & & & & \\
\hline
\end{tabular}

Table 3 shows that the mean scores of male students exposed to kagan instruction is 49.33 with standard deviation of 18.64, while the mean score of male students exposed to conventional method is 46.21 with standard deviation of 18.31. The t-calculated is 1.87 while the t-table is 1.96 . Thus the t-calculated is less than the table value; therefore, the null hypothesis is not rejected. This implies that there is no significant difference between the posttest means scores of male students exposed to Kagan instructional and conventional strategies. 
Table 4: The t-test showing the posttest mean scores of female students exposed to kagan instructional and conventional strategies

\begin{tabular}{|l|l|l|l|l|l|l|l|}
\hline Group & N & Mean & SD & Df & t-cal & t-table & result \\
\hline $\begin{array}{l}\text { Kagan Instructional } \\
\text { strategy }\end{array}$ & 25 & 29.74 & 2.80 & & & & Not Significant at $<0.05$ \\
\hline Conventional method & 20 & 27.54 & 2.84 & & & & \\
\hline
\end{tabular}

Table 4 shows that the mean scores of female students exposed to kagan instruction is 29.74 with standard deviation of 2.80, while the mean score of female students exposed to conventional method is 27.54 with standard deviation of 2.84 . The $\mathrm{t}$-calculated is 1.47 while the $\mathrm{t}$-table is 1.96 . Thus the $\mathrm{t}$-calculated is less than the $\mathrm{t}$-table value; therefore, the null hypothesis is not rejected. This implies that there is no significant difference between the posttest means scores of female students exposed to Kagan instructional and conventional strategies.

\section{Discussion}

The findings of the study revealed in hypothesis 1 that there is significant difference between the pretest mean scores of students exposed to kagan instructional and conventional strategies. This corroborated findings of the New South Whales Educational Standard Authority (NESA) which shared the view that students work better in teams to enhance their academic practice and was supported by Hooker (2010) who opined that students' interest and ability in science is a function of the cognitive, affective and collaboration for common purpose. The study also revealed in hypothesis 2 that there is a significant difference between the posttest means scores of students exposed to Kagan instructional and conventional strategies. This is in accordance with the submission of Yardam (2009), who asserted that peer instruction which is a sub set of Kagan instructional strategies increases the social interaction among students, hence affects the attitudes and performance of students positively. This was also supported in the study conducted by Connelly (2010) that apart from change in academic achievement, class wide peer tutoring also enhanced student motivation and promoted comprehension. It was therefore found from the study that students exposed to kagan instructional strategies performed better than those exposed to conventional method. The study also revealed in hypothesis 3 and 4 that there is no significant difference between the posttest mean scores of male and female students exposed to kagan instructional and conventional strategies. This was in accordance with Goodings and Merz's study (2011), that students' attitudes towards Sciences changed completely after participating in the small peer-led collaborative groups but gender had no significant contribution. This is an indication that gender has no significant contribution because male and female students exposed to the same treatment have nearly the same scores in the test.

\section{Conclusion}

Based on the findings of this study, it was found that Kagan instructional strategy was more effective in teaching Basic Science than the conventional method. The Kagan strategy allow students to construct their own meanings and scaffold what they are learning with their peers, there fore has the potency of producing higher students' performance. It was also discovered that sex does not play any significant role in students' achievement in Basic Science. Male and female students exposed to same treatment did not differ significantly in their performance.

\section{Recommendations}

Based on the findings, the researcher considers the following recommendations necessary:

1. Basic Science lecturers should adopt Kagan instructional strategies in lecture rooms to enable students participate actively and interact to arouse their interest and improve performance.

2. The College management should organize seminars at intervals for Basic Science lecturers to update their knowledge on the application of the Kagan instructional strategies

3. Government should provide enabling environment for lectures and making the school conducive for participatory studentship

\section{References}

Ali. S., Haider, Z., Munir, F., Khan, H., \& Ahmed, A. (2013). Factors contributing to student's academic performance: A case study of Islamia University Sub campus. American Journal of Educational Research

Cole, R.W. (2008). Educating Everybody's countries Diverse Teaching Strategies for Diverse learning (Revised and Explained $2^{\text {nd }}$ ed) Alexandra, V.A: Association for expression and curriculum development.

Davidson, N.(1994). Cooperative and Collaborative learning: An integrative Perspective in J.S. Thousand, R.A. Villa and A.A. Nerin (eds) creative and collaborate learning? A practical Guide to Empowering students and Teachers. 13 - 30 Baltimore, Md: Paul H.Brookes

Emmanuel B. (2009). The place of Nigeira Certificate in Education. Teachers in UBE Basic Science programme. Science Teachers Association of Nigeria (STAN)

Faroq, M.S. and Chaudry, A.H., (2011). Factors affecting students' quality of academic performance: A case of 
secondary level. Journal of Quality and Technology management 7(2), $01-14$.

Graybeal, S. S. \& Stodolsky, S. S. (1985). Peer work groups in elementary schools. American Journal of Education, 94, $409-428$

Gooding, J. \& Mertz, B. (2011). From misconceptions to conceptual change: Tips for identifying anf overcoming students' conceptual change. The Science Teacher $34-37$.

Huit, W. (2007). Success in the Conceptual Age: Another paradigm shift. Paper deliverd at the $32^{\text {nd }}$ Annual Meeting of the Georgia Educational Research Association. Savannah, GA, October 26, Retrieved (date), fromhttp://www.edpsycinteractive.org/papers/conceptual-age.pdf

Kagan, S. (2013). Kagan cooperative learning structures. Sam Clementine, CA: Kagan. 5.3

Kagan, S. (2011). The "P" and "I" or PIES: Pwerful principle for success; Kagan online magazine

Lerner, C., Ciervo, L. (2004). Getting ready for school Begins at Birth: How to Help your child learn in the Early Years (Brochure), Los Angels, C.A: Zero to Three.

NSW Education Standard Authiority: Www.nsw.Edu.au/wps/portal/nesa.

Snider, L.A. (2004). Teaching students to think using peer instruction and studentelectronic response (PISER) for the enhancement of conceptual and critical learning. Retrieved June2, 2007 from http://www.edd.nus.edu.sg/link/mar2004/tm2.htm 